\title{
Characterisation of Sanguinhal Mire, Terceira Island (Azores): a protected quaking bog habitat
}

\author{
Cândida Mendes ${ }^{1,2}$ and Eduardo Dias ${ }^{1}$
}

Received: June 27, 2008. Accepted: December 3, 2008

RESUMO - (Caracterização da Turfeira do Sanguinhal, ilha Terceira (Açores) um habitat protegido de turfeira ondulante). O Arquipélago dos Açores no Atlântico Norte é uma área importante em biodiversidade, rica em espécies e habitats raros em estado selvagem. A turfeira do Sanguinhal foi originalmente uma lagoa que evoluiu por paludificação para um habitat de turfa. Esta localiza-se na Rede Natura 2000 (União Europeia para a Proteção da Natureza e Biodiversidade, Directive do Conselho 92/43/EEC de 21 de Maio 1992 sobre a concervação de habitats naturais e da fauna e flora, Diretiva de Habitat Anexo I(b) habitat 7140) da Serra de Santa Bárbara e Pico Alto e é um bom exemplo de um tipo de turfeira de bacia, descoberto pela primeira vez em 1998. Este trabalho provê informações iniciais sobre a flora, as comunidades vegetais, a estrutura, as caracteristicas químicas da água e o regime hidrológico de superfície. Foram identificadas 41 espécies vegetais, incluindo 6 espécies do género Sphagnum, e 10 espécies de plantas vasculares endêmicas, forma identificadas oito comunidades vegetais. A profundidade máxima de turfa é de $2,5 \mathrm{~m}$. A turfeira recebe água superficial de suas margens, além da precipitação interceptada e da névoa. Depois das chuvas, a água é drenada por vários pontos da turfeira onde o placic se rompeu. $\mathrm{O} \mathrm{pH}$ e a condutividade das água foram medidos tendo-se verificado algumas tendências. O estado de conservação da turfeira é bom embora esteja sujeita a um crescente pastoreio por gado selvagem e a abertura de trilhos de forma desordenada altera o natural movimento de água na turfeira.

Palavras-chave: condutividade, Directiva Europeia de Habitats, hidrologia, pH, vegetação

ABSTRACT - (Characterisation of Sanguinhal Mire, Terceira Island (Azores): a protected quaking bog habitat). The Azores archipelago in the North Atlantic is an important area for biodiversity because it is rich in rare species and habitats, and almost undisturbed. Sanguinhal mire was originally a lake that evolved through paludification into a peat habitat. It is located inside Nature 2000 (European Union for Protection of Nature and Biodiversity, Council Directive 92/43/EEC of 21 May 1992 on the conservation of natural habitats and of wild fauna and flora, Habitat Directive Annex I(b) habitat 7140) area of Santa Bárbara and Pico Alto Mountains on the island of Terceira, and it is a good example of a basin peatland type that was first discovered in 1998. This paper provides baseline information on its flora, vegetation communities, structure, surface hydrology and chemistry. Forty-one plant species including six Sphagnum species and ten endemic vascular plants have been recorded, and eight plant communities are distinguished. The maximum peat depth is $2.5 \mathrm{~m}$. The mire receives flowing water from its margins, in addition to intercepted precipitation and fog. After precipitation, water drains through several placic rupture points. Both $\mathrm{pH}$ and water conductivity were measured, with some ecological tendencies observed. The conservation status of the mire is good, but it is subject to increasing pressure from cattle pasture and a walking trail that constrains natural surface water movement.

Key words: conductivity, European Habitats Directive, hydrology, pH, vegetation

\section{Introduction}

The Azores (Portugal) is the most northerly Macaronesian archipelago, comprising nine volcanic islands scattered over an area of approximately $1000 \mathrm{~km}^{2}$ in the North Atlantic between latitudes $36^{\circ} 56^{\prime} \mathrm{N}-39^{\circ} 42^{\prime} \mathrm{N}$ and longitudes $25^{\circ} 5^{\prime} \mathrm{W}-31^{\circ} 12^{\prime} \mathrm{W}$. The easternmost island, Santa Maria, is located approximately $1400 \mathrm{~km}$ from mainland Europe and the westernmost island, Flores, lies $1900 \mathrm{~km}$ from the North American continent. These islands host the most westerly mires in Europe. These peat formations are also the most important in the Macaronesian biogeographic region where peat formations are very scarce, due to inappropriate environmental conditions for peatland formation and development or human landscape transformation. Exploration of these rare landforms for Portugal was first proposed in 1922 (Zbszewski 1979), and some of the plant associations are included in the phytosociological system of Lüpnitz (1975). Otherwise, almost nothing was known about them until the mid-1990s.

The European Union (EU) Habitats Directive was the main instrument for the establishment and maintenance of a pan-European network of spaces, known as 'Natura 2000'.
Annexes I and II of this Directive list respectively the natural habitats and species for which protection network sites of Natura 2000 are required (EU 1992). Extremely rare entities are distinguished as "priority" for conservation purposes. In the Azores there are five types of protected peatlands (Codes 7110, 7120, 7130, 7140 and 91DO), and three of these are considered priority habitats (considered near extinction by Directive Habitats).

Management plans for the Azorean Natura 2000 areas were completed in 2004 and approved by the regional government in 2005. The information presented in this paper was compiled as part of the underpinning data collection exercise.

Dias (1996) developed the first classification of Azorean wetland vegetation, describing six distinct communities of which four are Sphagnum-dominated; whilst Mendes (1998) distinguished five Sphagnum mire types (based in topography and plant communities), namely basin, transition, raised, valleyside and blanket. The basin mires occur in strongly endorheic valleys. Although the water supply is predominantly meteoric, arriving as precipitation and intercepted thick fog, the mire margins are rich in hummocks with characteristic vascular species whose

\footnotetext{
1 Intergraph Registered Research Laboratory, Departamento de Ciências Agrárias, Universidade dos Açores, GEVA Terra, Chã, Angra do Heroísmo, Portugal

2 Corresponding author: cmendes@uac.pt
} 
development can be attributed to the ingress of water with entrained oxygen and nutrients from the surrounding mineral catchments. The hummocky peripheral zone is less extensive in steep catchments than in locations where the surrounding hillsides slope gently and thus drain sluggishly. Water is stagnant and the water table is usually at ground level in the swards at the centre of the basins. This basin mire reflects the actual process of succession, as peat accumulates in open water to produce rainwater-fed bog isolated from groundwater influence. Many of these systems are very unstable underfoot and can therefore also be described as 'quaking bogs'. Transition mires and quaking bogs have wide European distribution (European Environmental Agency 2008) but appear to be relatively scarce in the Mediterranean region (Joint Nature Conservation Committee 2008). These formations have never been described for the Macaronesian Region and are extremely rare in the Azores islands (until now found on Terceira and Flores islands). This paper presents a first description of this protected mire type and a first reference on water chemistry of Azorean mires, as a foundation for further research and publications.

The study area is on Terceira Island, located near the centre of the Azores archipelago and extends to approximately $402 \mathrm{~km}^{2}$. Its highest mountain, the Santa Bárbara volcano (1023 m), hosts the largest concentration of biodiversity within the natural areas of the Azores, and most of its biotopes are in excellent conservation condition. Thus the Natura 2000 Site of Community Importance (SCI) classified "Santa Bárbara Mountain and Pico Alto" as one of the biodiversity hotspots of the Macaronesian biogeographic region, with 18 protected habitats and 10 protected species, of which five habitats and two species have priority status.

The Sanguinhal Mire is a basin mire located at an altitude of $570 \mathrm{~m}$ above sea level within the SCI (Fig. 1) and is regarded as an example of the Annex I(b) habitat 7140 ("transition mire and quaking bogs") defined (European Commission DG Environment 1999) as peat forming communities developed at the surface of oligotrophic to mesotrophic water, with characteristics intermediate between soligenous and ombrogenous types.

The area of the mire is $74,985 \mathrm{~m}^{2}$, and its watershed extends to $897,314 \mathrm{~m}^{2}$. The soil of the study area is classified as histosol (see Montanarella et al. 2006), giving way at its margins to andosols with placic horizons. The latter are modern soils with high organic matter content, developed from volcanic pyroclastic material in a wet temperate Atlantic climate (Pinheiro 1990; Madruga 1995). The presence of a placic horizon (Bsm horizon characterised by the accumulation of iron and magnesium, also known as an 'iron pan' or 'iron band') is an important ecological factor because it restricts soil drainage.

Precipitation ranges from 4,109 $\mathrm{mm} \mathrm{yr}^{-1}$ at $600 \mathrm{~m}$ a.s.1. to 13,054 $\mathrm{mm} \mathrm{yr}^{-1}$ at $980 \mathrm{~m}$ a.s.l. (Dias 1996). The ecological conditions at altitudes above $500 \mathrm{~m}$ are so favourable for the development of wet vegetation complexes that, with some exceptions like lava domes (Dias 1996; Dias et al. 2004; Elias \& Dias 2004), the majority of the vegetation consists of mire communities or is directly dependent on mires.

The hydrological catchments' area has some natural shrub vegetation, but is dominated by grassland characterized by an increasing cattle pasture. The existence of walking trails that pass through the mire is responsible for serious hydrological changes in the mire, with the development of several hummock communities (in the east part).

\section{Material and methods}

A map of the mire was made from aerial photographs and subsequently adjusted using data collected in the field. Floristic composition was recorded in $5 \mathrm{~m} \times 5 \mathrm{~m}$ relevés using the cover classes of Braun Blanquet (Westhoff \& Maarel 1978). Nomenclature followed Dias (2004) for vascular plants, and Smith (1980) and Sjögren (2001) for mosses. Plant communities were identified on the basis of the species with the highest cover values. Each community was also characterised in terms of its dominant micro-relief. The vegetation map was developed from aerial and local photographs and GPS (Global
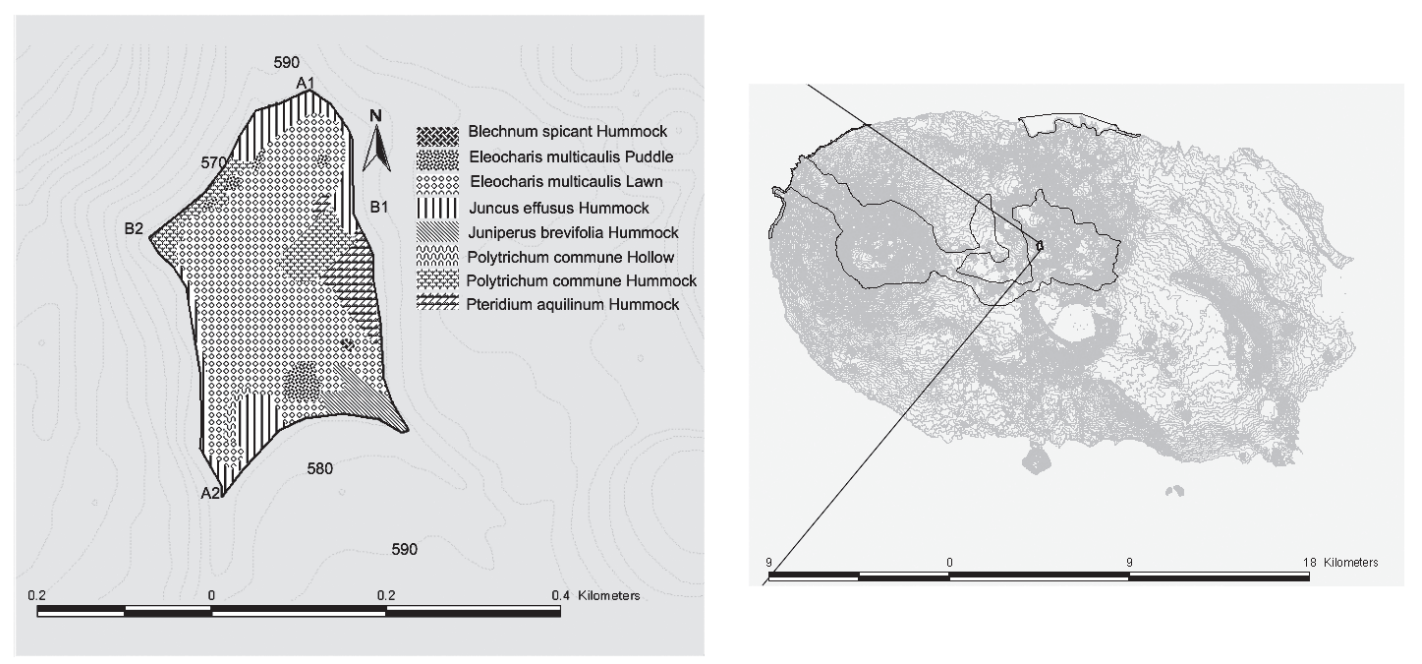

Figure 1. Map of Terceira Island showing the location of the Sanguinhal mire in relation to the boundary of the Santa Bárbara Mountain and Pico Alto SCI. Vegetation communities distribution map in the Sanguinhal mire delimitation. A1, A2, B1 and B2 are the initial and final locations of the peat depth profiles. 
Position System) points in a Geomedia environment by GEVA, an Intergraph Registered Research Laboratory.

Water chemistry and depth of the mire are important for determining ecological niches of plant species present in mires (Bragazza 1999). $\mathrm{pH}$ and conductivity were measured in the field using WTW pH 320 - pH Meter and WTW LF - Conductivity Meter. The depth of peat was measured. For this purpose, two profiles were laid out with PVC tubes, along the major and minor axes of the mire respectively (Fig. 1).

Ecological attributes of wetlands such as floristic diversity, vegetation and peat characteristics depend upon the maintenance of their hydrology. Therefore a preliminary analysis of surface water movement was carried out using the Watershed Delineator extension to the ArcView GIS package (see e.g. Romanek 1998).

\section{Results}

Vegetation - The vegetation of the Sanguinhal recorded 29 phanerogamic and 12 cryptogamic species. The most representative phanerogam families, in number of species, are Poaceae and Ericaceae and the richest cryptogam family is Sphagnaceae (Fig. 2). Three species, Culcita macrocarpa C. Presl (Fig. 3), Erica azorica Hochst. (Fig.2) and Frangula azorica V. Grubow are listed in Annex II of the EU Habitats Directive and another six are listed in Annex V of the same Directive. Eight plant communities were distinguished (Tab. 1).

The specie Eleocharis multicaulis (Sm.) Desv. dominates in two different communities, in swards (Fig. 3) and in pools. The sward community is the predominant one, occupying $61 \%$ of the mire. It has 12 species including 5 bryophytes. It forms remarkably homogeneous swards which are perennially waterlogged, with a maximum summer water table depth of $10 \mathrm{~cm}$. Several small pools occur in the mire, always dominated by Eleocharis multicaulis (Sm.) Desv. where 7 species were identified, including 4 belonging to Sphagnum. Polytrichum commune Hewd. forms a dense sod community occurring in two micro-relief forms, hummock ( $9 \%$ of the mire area) and hollow ( $1 \%$ of the mire area), with ecological and floristic differences between the two. In the dry hummock formation we identified 19 species and 10 in wet hollow.

Four other hummock communities were identified, developed in the far eastern part of the mire. These communities occur due to a drop in water level associated with hydrological changes owed to the presence of the walking trail that changes the water course of two water lines. The Juncus effusus L. formation (Fig. 3) occupies 15\% of the mire; it has 10 phanerogamic species, including 6 mosses, and is described as preferring wet acid environment with slightly enriched nutrient conditions and seasonal water level fluctuations (McCorry \& Renau 2003). This community occurs at the extremes, where hillside-drained waters rich in nutrient and oxygen, enter the mire. The Pteridium aquilinum (L.) Kuhn community (Fig. 3) consists of 14 species and covers $6 \%$ of the mire. This plant is indicative of soil nitrous conditions showing that organic decomposition is occurring in the mire, probably due to hydrological changes derived from the existence of walking trails that deviate water outside this peat formation.
The Juniperus brevifolia (Seub.) Antoine community (Fig. 3, Tab. 1) represents only $4 \%$ of the mire area but is the richest formation in plant biodiversity with 27 species, including the indicator moss Leucobryum glaucum (Hedw.) Angstr and the three species protected by Annex II of Habitat Directive.

The community dominated by Blechnum spicant (L.) Roth has 10 species. In the basin mire study in Terceira Island this community was restricted to this mire, occupying $147 \mathrm{~m}^{2}(0.1 \%$ of the mire area).

Peat -The data collected indicate that maximum peat depth is $2.5 \mathrm{~m}$ (Fig. 4), the average depth is $1.69 \mathrm{~m}$ on the long axis of the mire (Transect A) and $1.62 \mathrm{~m}$ on the shorter axis (Transect B) (Fig. 1). Below the peat layer there is an unknown mass of water. The volume of peat accumulated is about $157,000 \mathrm{~m}^{3}$, underlining the importance of the basin mire for water storage.

Surface hydrology - Surface water movement within the catchment area $\left(897,314 \mathrm{~m}^{2}\right)$ of the mire is directed predominantly towards the peatland. The principal inflows were two water lines, located in the Northeast and in the Southeast, now partially altered due to the walking trails. There are several points north of the mire where the placic is broken and the water flows to deep halls out the mire. Water chemistry and water depth - The 20 mire-water samples collected and analysed are too few to offer generalizations regarding patterns in water chemistry but they allow us to set up tendencies for these parameters for each community studied. The study of $\mathrm{pH}$ and conductivity was repeated in all plant communities in all 58 studied mires on the island, (until now we verify differences throughout the year), associated with the level of precipitation. In this mire average $\mathrm{pH}$ varies between 4.9 in Pteridium aquilinum (L.) Kuhn hummock community and 4.3 in Polytrichum commune Hewd hummock community (Tab. 2). Average conductivity varies between $98.7 \mu \mathrm{s} / \mathrm{cm}$ in Pteridium aquilinum (L.) Kuhn hummock community and $66.7 \mu \mathrm{s} / \mathrm{cm}$ in Eleocharis multicaulis (Sm.) Desv. pool community. Both $\mathrm{pH}$ and conductivity increase with water depth. A correlation analysis shows a correlation between $\mathrm{pH}$ and water depth of $51 \%$ and a correlation of $67 \%$ between conductivity and water depth (Tab. 3). In all mire surface water is at or near the surface (30 $\mathrm{cm}$ maximum) showing that represents an important water structure.

\section{Discussion}

Quaking bogs are peatlands that evolved from a lake. These communities are rare in southern Europe. In the Azores these are also rare but are known on Terceira and Flores islands. On Terceira Island, the other quaking bog studied is located in a more natural area at $1000 \mathrm{~m}$ altitude; it has 18 phanerogams and 13 cryptogams including 6 protected vascular species (Dias \& Mendes 2007). Flores island quaking bogs need further investigation to detail its floristic and hydrologic importance (some data in Dias et al. 
2004). This peat habitat type is important in terms of the presence of rare and protected species of the Azores islands, for example Azorean humid laurel forest, considered a rich formation, has (according to data from Dias 1996), 12 vascular endemic species. Besides floristic richness and hydrologic importance, several protected habitats (e.g. laurel forest and Juniperus forests) and several protected species (e.g. Angelica ligniscens and Chaerophyllum azoricum) depend on the nutrients and water drained from altitude peatlands (Dias et al. 2004).

A study of 16 lake-fill peatlands in Indiana (United States) identified a total of 131 vascular plants and 49 bryophytes (Swinehart et al. 2001), but it includes fens and forested peatlands. Data related to bogs (average size 20 ha) of the above-mentioned study reached an average of 20 species for each bog. Considering the size and number of species of these American quaking bogs, studied Azorean formation is rich in plant diversity. Rodwell et al. (1991) described British mire communities, but does not identify any community that corresponds in species composition to the ones distinguished in this study. Related to plant diversity this same author cites numbers between 7 (in Sphagnum auriculatum pool communities) and 20 species (in Calluna vulgaris dominated communities). So, also comparing with related European formation Azorean studied quaking bogs are rich in plant diversity.
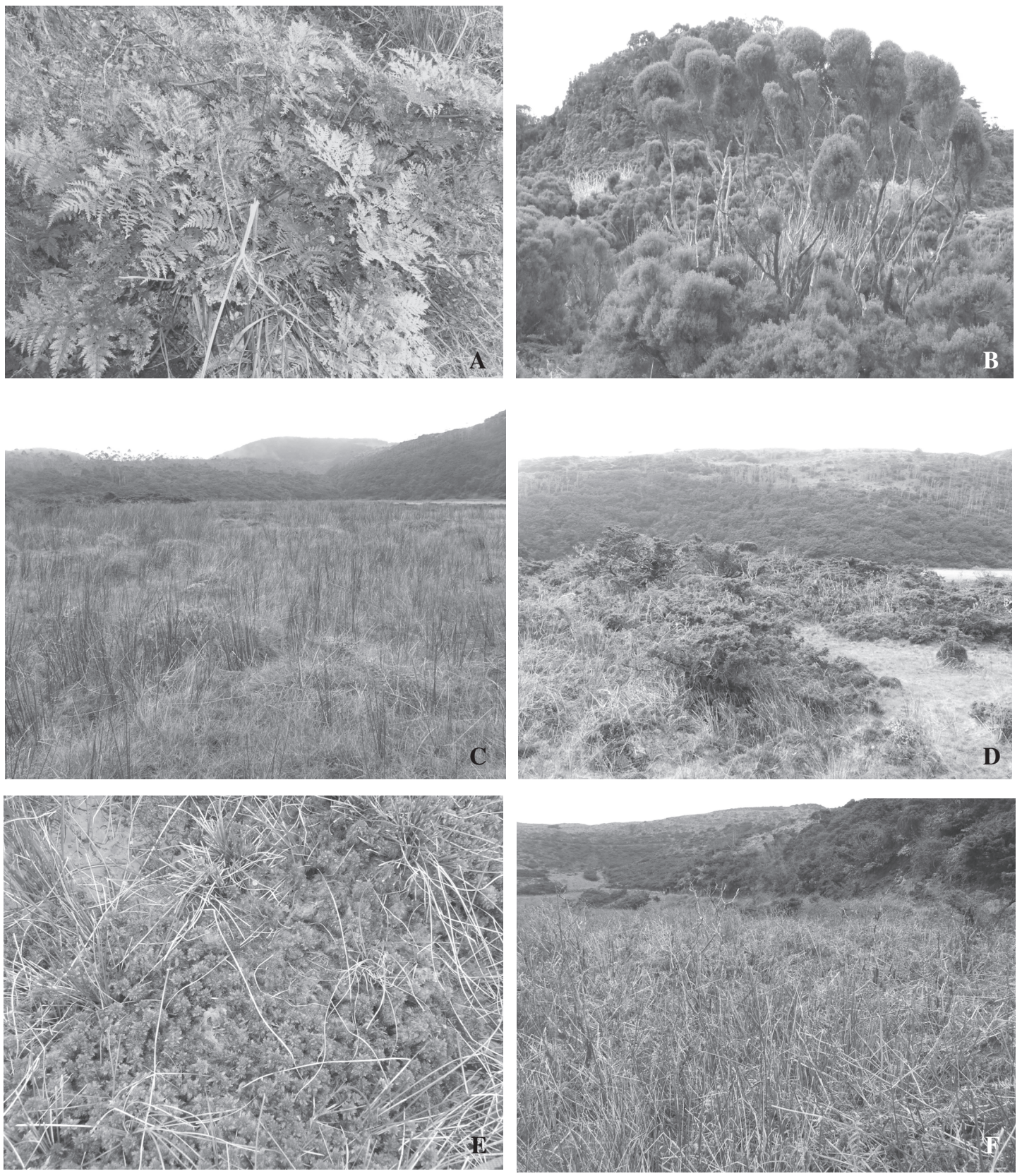

Figure 2. A. Culcita macrocarpa C. Presl protected species. B. Erica azorica Hochst. protected species. C. Juncus community. D. Juniperus community. E. Eleocharis community. F. Pteridium community. Sanguinhal mire. Source: AZU photo database 


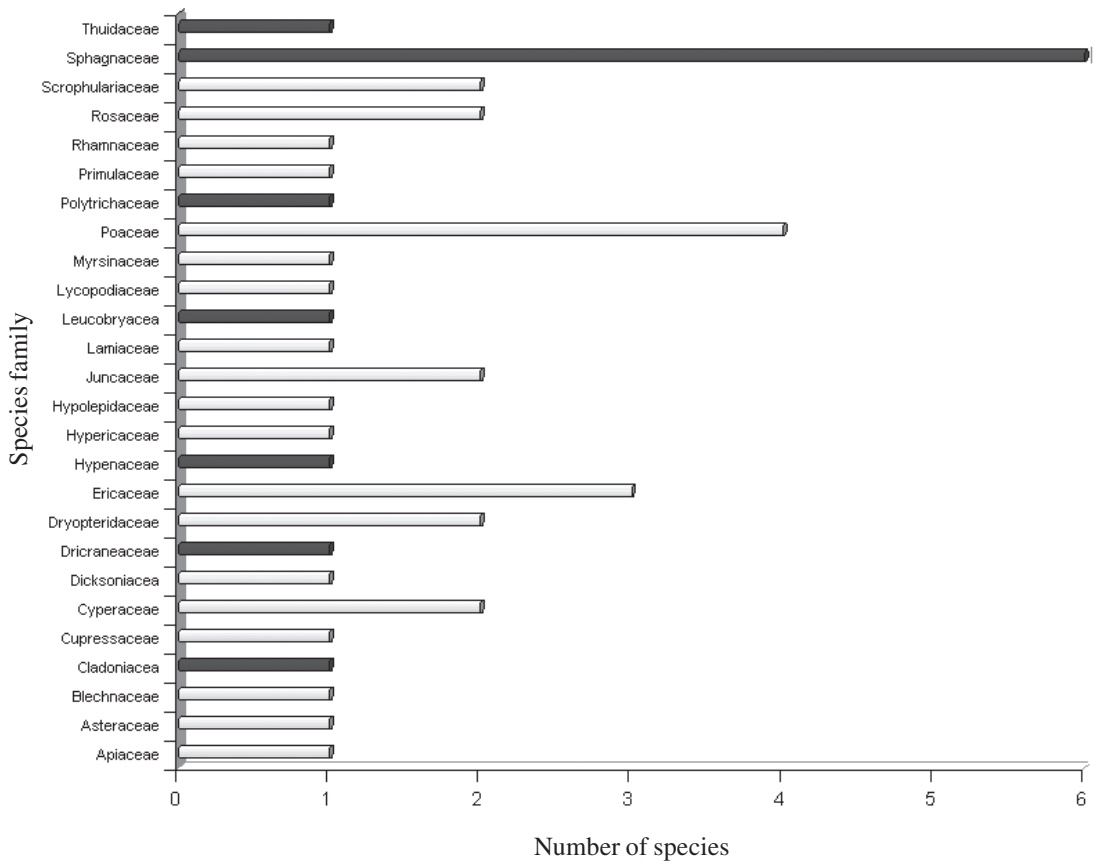

Figure 3. Taxonomic classification of plant survey in Sanguinhal mire in Families.

The Sanguinhal mire is very small compared, for example, to mires in Finland, some of which cover more than 17,000 ha (Lappalainen 1996). Size must, however, be considered at the regional level.

Paavilainen \& Päivanen (1995) adopt a very liberal definition of mires for Finland, based on the presence of peat-forming species without specifying a minimum peat depth. For Canada, on the other hand, Keys (1992) and Zoltai \& Polet (1983) define mire as a community in which the accumulation of organic matter is confirmed by the
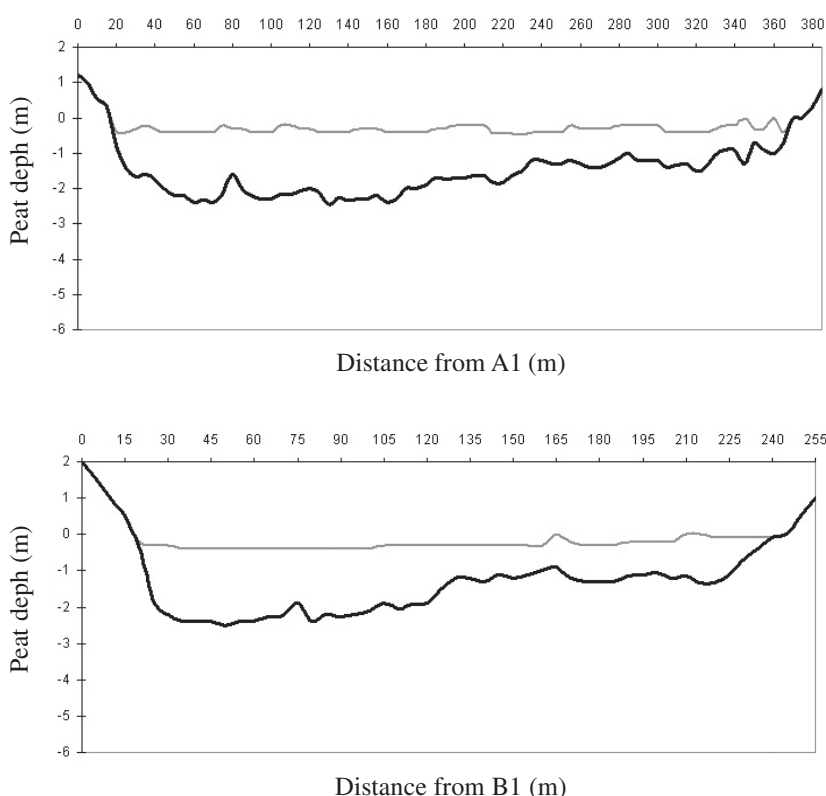

Figure 4. Peat depth profiles of the Sanguinhal mire: Transect A1-A2 and B1B2 (see Fig. 1). presence of a minimum depth of $40 \mathrm{~cm}$ of peat. In the present study, the view was taken that a development phase is required for peat formation to reach equilibrium, and all peat less than $70 \mathrm{~cm}$ deep is considered to be young. In these terms, the Sanguinhal mire is a mature mire with up to $2 \mathrm{~m}$ of peat; however, the deepest mire on Terceira Island has $6 \mathrm{~m}$ of peat (Mendes 1998). This water reservoir is extremely important, especially on islands with limited water resources.

Water $\mathrm{pH}$ and conductivity are correlated with water depth. Studies of hydrologic conductivity in a upland blanket peatland (Holden \& Burt 2003) confirm the correlation between conductivity and depth, assuming that this is more relevant in the first centimetres of the peat layer. More generic studies are being prepared for publication to confirm in detail these correlations. However the values presented are the first international reference to Azorean mire water properties. The values of $\mathrm{pH}$ obtained in this study, varying between 3.8 and 5.5 are characteristic of bog formations, with $\mathrm{pH}$ below 5.5 (Nakamura et al. 2002).

Peatlands in their natural state are inhospitable habitats for many wildlife species. This is due to a number of factors including low nutrient status of peatland soils, waterlogged surface conditions and scarcity of tree cover capable of providing shelter. Sphagnum dominates the ground surface and is the main constituent of peat due to its ability to grow under such acid, low-nutrient and waterlogged conditions. The Sanguinhal is rich in diversity for this genus, with records for six of the 12 Sphagnum species that occur on the entire Azores archipelago (Sjögren 2001). Indeed, with 41 plant species, this is a peatland with high biodiversity levels for the vegetation as a whole, since only 76 species 


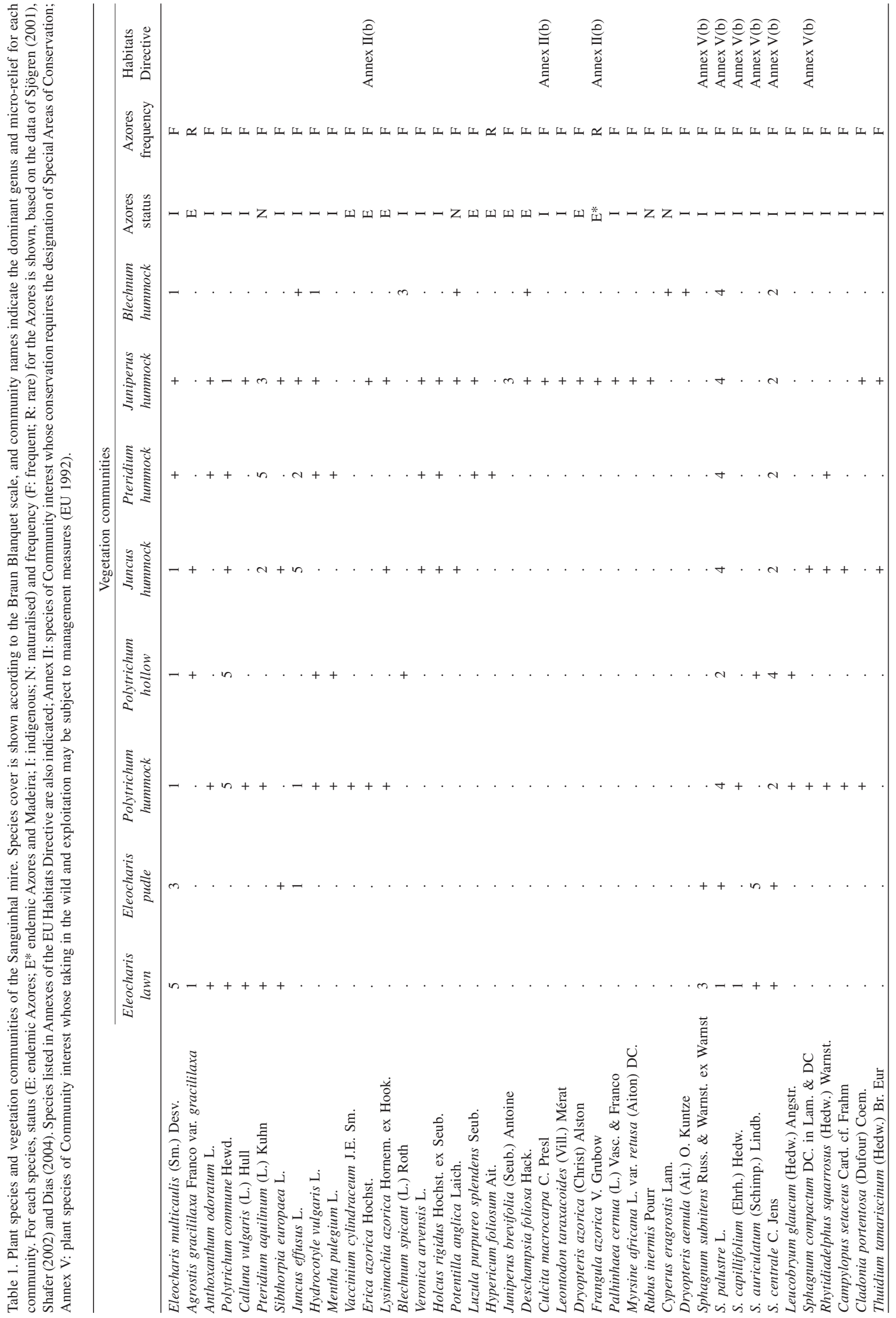


Table 2. $\mathrm{pH}$, Conductivity and water depth average of Sanguinhal mire considering its plant communities. These samples were collected and analysed in the summer of 2006.

\begin{tabular}{|c|c|c|c|c|c|c|c|c|}
\hline & \multicolumn{8}{|c|}{ Vegetation communities } \\
\hline & $\begin{array}{c}\text { Eleocharis } \\
\text { lawn }\end{array}$ & $\begin{array}{c}\text { Eleocharis } \\
\text { pudle }\end{array}$ & $\begin{array}{l}\text { Polytrichum } \\
\text { hummock }\end{array}$ & $\begin{array}{l}\text { Polytrichum } \\
\text { hollow }\end{array}$ & $\begin{array}{c}\text { Juncus } \\
\text { hummock }\end{array}$ & $\begin{array}{l}\text { Pteridium } \\
\text { hummock }\end{array}$ & $\begin{array}{l}\text { Juniperus } \\
\text { hummock }\end{array}$ & $\begin{array}{l}\text { Blechnum } \\
\text { hummock }\end{array}$ \\
\hline Samples & 6 & 3 & 1 & 1 & 4 & 1 & 2 & 2 \\
\hline $\mathrm{pH}$ & 4,5 & 4,6 & 4,3 & 4,4 & 4,3 & 4,9 & 4,5 & 4,3 \\
\hline Standard deviation & 0,3 & 0,6 & - & - & 0,2 & - & 0,1 & 0,4 \\
\hline Conductivity $(\mu \mathrm{s} / \mathrm{cm})$ & 71,3 & 67,3 & 70,5 & 68,3 & 86,6 & 70,7 & 99,2 & 112,1 \\
\hline Standard deviation & 9 & 1,2 & - & - & 6,6 & - & 12,7 & 5,1 \\
\hline Water level (cm) & -2 & 10 & -4 & 0 & -10 & -7 & -3 & -10 \\
\hline Standard deviation & 0 & 0 & - & - & 5 & - & 4 & 15 \\
\hline
\end{tabular}

Table 3. Correlation analysis of $\mathrm{pH}$, conductivity and water depth. Data from 48 water samples of Sanguinhal mire collected and analysed in the summer of 2006 and 2008.

\begin{tabular}{lccc}
\hline & $\mathrm{pH}$ & $\begin{array}{c}\text { Conductivity } \\
(\mathrm{ms} / \mathrm{cm})\end{array}$ & $\begin{array}{c}\text { Water detph } \\
(\mathrm{cm} \text { beneath surface })\end{array}$ \\
\hline $\mathrm{pH}$ & 1 & & \\
Conductivity $(\mathrm{ms} / \mathrm{cm})$ & 0,47 & 1 & 1 \\
Water detph (cm beneath surface) & 0,51 & 0,67 & 1 \\
\hline
\end{tabular}

were identified during a survey of 58 basin mires on Terceira Island, with an average of 24 species per site (Mendes 1998).

The good conservation status of this peatland is demonstrated by the fact that the 41 plant species recorded include ten endemics (three of which are regarded as rare), three protected species and contains no exotic species for the island (Tab.1). The Sanguinhal Mire is a typical example of the basin mires on Terceira Island in that it has a marginal community which is dominated by Juncus effusus L. Seven additional plant communities have been identified, two dominated by Eleocharis multicaulis (Sm.) Desv (pools and swards), two dominated by Polytrichum commune Hewd. (hummock and hollows), one by Pteridium aquilinum (L.) Kuhn, Blechnum spicant (L.) and Juniperus brevifolia (Seub.) Antoine (all in hummocks).

It is important that the pasture on this mire watershed be controlled. Measures should be taken to minimize the impact of the walking trail, in order to maintain (even improve) water quantity and quality for the Sanguinhal mire itself but also for the other dependent habitats downstream.

Given the importance of peatlands, even if viewed no more widely than at regional scale, this is the first work that allows a detailed description of an Azorean Sphagnum quaking mire. It provides a starting-point for building an understanding of these complex habitats, but also reveals an urgent need for the acquisition of further knowledge to support measures for their conservation. However, the fact that most of the Terceira Island mires lie within Natura 2000 areas is likely to favour their conservation and study.

\section{References}

Bragazza, L. 1999. Spatial patterns of plant species in a poor mire on the Southern Alps (Italy). Plant Biosystems 133: 83-92.
Dias, E. (1996) Vegetação Natural dos Açores. Ecologia e Sintaxonomia das Florestas Naturais (Natural Vegetation of the Azores. Ecology and Syntaxonomy of Natural Forests). $\mathrm{PhD}$ Dissertation, Department of Agricultural Sciences, Azores University, Angra do Heroísmo (in Portuguese).

Dias, E. 2004. Lista de Referência da Flora dos Açores (Reference List of the Flora of the Azores). Applied Vegetation Ecology Investigation Group, Azores University, Angra do Heroísmo. http://www.angra.uac.pt/geva/WEBGEVA/Scheklistacores/ ScheklistAcoresstart.htm (in Portuguese).

Dias, E; Elias, R. \& Nunes, V. 2004. Vegetation mapping and nature conservation: a case study in Terceira Island (Azores). Biodiversity and Conservation 13: 1519-1539.

Dias, E., Mendes, C.; Melo, C.; Pereira, D.; Elias R.; Elias S. \& Pereira, F. 2004. Plano de Gestão Sectoriais das áreas Terrestres da Rede Natura 2000 dos Açores (Sectorial Management Plans of Azores Natura 2000 Terrestrial Protected Areas). Departamento de Ciências Agrárias. Universidade dos Açores \& Direcção Regional dos Serviços de Ambiente.

Dias, E. \& Mendes C. 2007. Characterization on a Basin Mire in the Azores Archipelago. Mires and Peat. v. 2 Article 8, http:// www.mires-and-peat.net

Elias, R. \& Dias, E. 2004. Primary succession on lava domes on Terceira (Azores). Journal of Conservation Science 15: 331-338.

EU 1992. Council Directive 92/43/EEC of 21 May 1992 on the conservation of natural habitats and of wild fauna and flora. Available online at: http://ec.europa.eu/environment/ nature/nature_conservation/eu_nature_legislation/ habitats_directive/index_en.htm

European Environmental Agency 2008. Transition mires and quaking bogs. Available online at: http://eunis.eea.europa.eu/ habitats-factsheet.jsp?tab $=1 \&$ idHabitat $=10145$

Holden, J. \& Burt, T.P. 2003. Hydraulic conductivity in upland blanket peat: measurement and variability. Hydrological Processes 17: 1227-1237.

Joint Nature Conservation Committee 2008. 7140 Transition mires and quaking bogs. Available online at: http:// www.jncc.gov.uk/ProtectedSites/S ACSelection/ habitat.asp?FeatureIntCode $=\mathrm{H} 7140$

Keys, D. 1992. Canadian peat harvesting and the environment. Sustaining Wetlands 3: 1-14.

Lappalainen, E. 1996. Peatlands and peat resources in Finland. Pp. 36-38. In: H. Vasander (ed.). Peatlands in Finland, Finnish Peatland Society, Helsinki.

Lüpniz, D. 1975. Geobotanische Studien zur Natürlichen Vegetation der Azorean unter Berücksichtigung der Chorologie innerhalb Makaronensis (Geobotanical studies of the natural vegetation of the Azores) Beitr. Biol. Pflazen 51: 149-317 (in German).

Madruga, J. 1995. Caracterização e génese do horizonte plácico em solos vulcânicos do arquipélago dos Açores (Chacterization and genesis of the placic horizon in the volcanic soils of the Azores Archipelago). PhD dissertation, Azores University, Angra do Heroísmo (in Portuguese). 
McCorry, M. \& Renou F. 2003. Ecology and managent of Juncus effusus (soft rush) on cutaway Peatlands. Forest Ecossystem Research Group. Report Number 69. Department of Environmental Resource Management. University College Dublin. Dublin 4.

Mendes, C. \& Dias, E. 2002. Ecologia e Vegetação das Turfeiras de Sphagnum da Ilha Terceira - Açores (Ecology and Vegetation of the Sphagnum mires of Terceira Island - Azores). Herbário da Universidade dos Açores, Angra do Heroísmo (in Portuguese).

Mendes C. 1998. Contributo para a Caracterização das Turfeiras de Sphagnum da ilha Terceira (Contribution to the characterisation of Sphagnum mires of Terceira Island). Relatório de Estágio, Universidade dos Açores, Angra do Heroísmo (in Portuguese).

Montanarella, L.; Jones, R.J.A. \& Hiederer, R. 2006. The distribution of peatland in Europe. Mires and Peat, 1: 1-10. http:// www.mires-and-peat.net/map01/map_1_1.htm.

Paavilainen, E. \& Päivanen, J. 1995. Peatland Forestry: Ecology and Principles. Ecological Studies 111, Springer-Verlag, Berlin.

Pinheiro, J. 1990. Estudo dos principais tipos de solos da ilha Terceira-Açores (Study of the major soil types of Terceira Island, Azores). PhD dissertation, Azores University Department of Agricultural Sciences, Angra do Heroísmo (in Portuguese).

Rodwell, J.S. (ed.); Pigott, C.D.; Ratcliffe D.A.; Malloch, A.J.C.; Birks, H.J.B.; Proctor, M.C.F.; Shimwell, D.W.; Huntley J.P.; Radford E.; Wigginton, M.J. \& Wilkins P. 1991. British Plant Community: Mires and Heaths. v.2. Cambrigde, UK Joint Nature Conservation Comittee. Cambridge University Press.
Romanek, A. 1998. GIS Enviro98 - Environmental Representation. Center for Research in Water Resources. The University of Texas at Austin. http://www.crwr.utexas.edu/gis/ gisenv98/envrep/envrep.html

Shäfer, H. 2002. Flora of the Azores. Margraf Verlag, Weikersheim, DE.

Sjögren, E. 2001. Distribution of Azorean Bryophytes up to 1999, their island distribution and information on their presence elsewhere, including Madeira and Canary Island. Boletim do Museu Municipal do Funchal, Sup. 7: 1-89.

Smith, A. 1980. The Moss Flora of Britain and Ireland. Cambridge University Press.

Swinehart, A.L.; Parker, G.R. \& Wujek, D.E. 2001. The structure and composition of vegetation in the lake-fill peatlands of Indiana. Proceedings of the Indiana Academy of Sciences 110: $51-78$.

Nakamura T.; Uemura S. \& Yabe, K. 2002. Hydrochemical Regime of Fen and Bog in North Japanese Mires as an Influence on Habitat and Above-Ground Biomass of Carex Species. The Journal of Ecology 90: 1017-1023.

Zbyszewsli, G. 1979. Ocorrências de Turfas em Portugal (The occurrence of peat in Portugal). Boletim de Minas, Direcção Geral de Geologia e Minas 6: 137-216.

Zoltai, S.C. \& Pollet, F.C. 1983. Wetlands in Canada: their classification, distribution and use. Pp. 245-268. In: A.J.P. Gore (ed.). Mires: Swamp, Bog, Fen and Moor. Regional Studies. Ecosystems of the World, 4B, Elsevier, Amsterdam.

Westhoff, V. \& Maarel, E. 1978. The Braun-Blanquet approach. Pp. 289-398. In: R.H. Whittaker (ed.). Classification of Plant Communities, Junk, The Hague. 